PRÁVNE ROZPRAVY ON-SCREEN III. - Sekcia súkromného práva

online vedecká konferencia - 7. máj 2021

\title{
POPÍRÁNÍ DOMNĚNKY OTCOVSTVÍ VÁZANÉ NA SOUHLAS K PROVEDENÍ UMĚLÉHO OPLODNĚNÍ: OTAZNÍKY ČESKÉ PRÁVNÍ ÚPRAVY
}

DENIAL OF THE PRESUMPTION OF PATERNITY BOUND TO A CONSENT TO ARTIFICIAL INSEMINATION: UNCLARITIES OF THE CZECH LEGAL REGULATION

Denisa Kotroušová ${ }^{1}$

https://doi.org/10.24040/pros.07.05.2021.ssp.126-140

\begin{abstract}
Abstrakt
Př́spěvek je zaměren na jednu z domněnek otcovství existujících v české právním řádu, konkrétně na domněnku vázanou na souhlas k provedení umèlého oplodnéní. Po vymezení základního právního rámce je primární pozornost je věnována otázce jejího popírání, jež není právní úpravou komplexně rešeno, a které však má zásadni význam zejména pro rodiče dítěte i samotné ditě počaté z umělého oplodnění. Mezi hlavni otázky patř́ otázka popěrných lhůt, okruhu osob s popěrným právem i podmínek pro popření otcovství. Zvažovány zde jsou různé výkladové možnosti pro vyplnění právní úpravy i dílči návrhy de lege ferenda.
\end{abstract}

\section{Kl’účové slová}

rodinné právo; otcovství; umělé oplodnění; asistovaná reprodukce; popěrná lhůta; domněnka otcovství; informovaný souhlas

\begin{abstract}
The contribution is focused on one of the presumptions of paternity existing in the Czech law - the presumption bound to consent to artificial insemination. After the introductory explanation of the legal framework, the attention is put on the denial of this presumption. This issue is not comprehensively regulated in the Czech Civil Code, although is of great importance for both parents and the child conceived via artificial insemination. The main questions discussed here are denial periods, subjects allowed to challenge the presumption, or conditions for denial. The contribution considers different interpretive options and suggests partial de lege ferenda ideas.
\end{abstract}

\section{Keywords}

Family Law; Paternity; Artificial Insemination; Assisted Reproduction; Denial Period; Presumption of Paternity; Informed Consent

\footnotetext{
${ }^{1}$ Mgr. Bc. Denisa Kotroušová - autorka je interní doktorandkou na Katedře občanského práva Právnické fakulty Západočeské univerzity v Plzni.
} 


\section{PRÁVNE ROZPRAVY ON-SCREEN III. - Sekcia súkromného práva}

online vedecká konferencia - 7. máj 2021

\section{Úvod}

Otázka určování a popírání otcovství patří (spolu s určením a popřením mateřství) mezi jeden ze základních pilírư rodinného práva obecně. Jinak tomu není ani v České republice. Česká právní úprava vychází ze systému vyvratitelných právních domněnek, z nichž se následující příspěvek zaměřuje na tu historicky nejmladší. Domněnka otcovství navázaná na udělení souhlasu k provedení umělého oplodnění reaguje na medicínský pokrok posledních desetiletí, v občanském zákoníku se jí však nedostává takového prostoru, jako ostatním. Tento faktor může působit mnoho otázek nejen teoretického, ale též praktického významu (zejména pro dotčené osoby, tedy rodiče dítěte a dítě samotné), a to především v souvislosti s jejím popíráním.

Příspěvek nejprve stručně přibližuje v prvé kapitole právní rámec určení a popření otcovství. Na první kapitolu navazuje kapitola druhá, jež se věnuje domněnce vázané na udělení souhlasu k provedení umělého oplodnění a vymezuje i obecný právní rámec asistované reprodukce, jakožto problematiky neodmyslitelně související. Kapitola třetí analyzuje naznačené problematické aspekty spjaté stouto domněnkou, přičemž hlavní pozornost klade na otázku absentujících popěrných lhůt a důsledky jejich absence v různých situacích, v nichž se může tato domněnka uplatnit. Mimo analýzy současného právního stavu se př́ispěvek pokouší též nalézt způsoby překlenutí této mezery v zákoně, a to jak úvahou nad aktuálními př́stupy odborné literatury, tak vlastní úvahou de lege ferenda.

\section{Obecný právní rámec určování a popírání otcovství v České republice}

Jak již bylo naznačeno v úvodu, česká právní úprava určování a popírání otcovství je založena na konceptu vyvratitelných právních domněnek vycházejících z určité zkušenosti a pravděpodobnosti, že otcem dítěte je muž, jemuž svědčí, přičemž není-li tomu tak, je připuštěno, aby subjekt tohoto právního vztahu prokázal opak. ${ }^{2}$ Občanský zákoník ${ }^{3} \mathrm{v}$ části druhé obsahuje čtyřri hierarchicky seřazené domněnky otcovství. První z nich, upravená v § 776 odst. 1 ObčZ, je tradiční - svědčí manželu matky dítěte, které se narodilo za trvání manželství či v ochranné době 300 dnů po jeho zániku či prohlášení za neplatné, či

\footnotetext{
${ }^{2}$ Rozsudek Nejvyššího soudu ze dne 18. 3. 2010, sp. zn. 23 Cdo 5508/2007.

${ }^{3}$ Zák. č. 89/2012 Sb., občanský zákoník, ve znění pozdějších předpisů (dále jen „ObčZ“).
} 


\section{PRÁVNE ROZPRAVY ON-SCREEN III. - Sekcia súkromného práva}

online vedecká konferencia - 7. máj 2021

prohlášení manžela za nezvěstného. Poprrít tuto domněnku mohou manžel a matka dítěte. Matka dítěte tak může učinit ve lhůtě 6 měsíců od narození dítěte ( $\$ 789$ ObčZ), a manžel v subjektivní lhůtě 6 měsíců ode dne, kdy se dozvěděl o okolnostech zakládajících důvodnou pochybnost o jeho otcovství, přičemž je současně limitován objektivní lhůtou 6 let ode dne narození dítěte (§ 785 odst. 1 ObčZ).

Chronologicky druhou domněnku otcovství představuje v § 778 ObčZ upravená domněnka svědčící muži, jenž udělil souhlas k provedení umělého oplodnění ženy neprovdané. Tato domněnka je ústředním předmětem zkoumání tohoto př́íspěvku a v detailu je o ní pojednáno v následujících kapitolách.

V pořadí třetí domněnka je opět vcelku tradiční - na jejím základě je za otce považován muž, který spolu s neprovdanou ženou, resp. matkou dítěte, učinil souhlasné prohlášení o otcovství před matričním úřadem či soudem ( 7779 ObčZ). I tuto domněnku mohou matka a otec dítěte popřít, a to ve lhůtě 6 měsíců ode dne učinění prohlášení, příp. ode dne narození dítěte, učinili-li je ještě před jeho narozením (§ 790 a $§ 791$ ObčZ). Do této domněnky otcovství má právo za splnění podmínek $§ 793$ ObčZ zasáhnout též soud z moci úřrední.

Konečně poslední, tzv. zbytková domněnka, na jejímž základě je otcovství určováno v rámci soudního řízení, je vymezena v $§ 783$ odst. 2 ObčZ, a přichází na řadu tehdy, nebyloli otcovství určeno jiným způsobem. V tomto př́ípadě svědčí otcovství muži, jenž s matkou dítěte souložil v rozhodné době 160 až 300 dnů před narozením dítěte, ledaže jeho otcovství vylučují závažné okolnosti.

\section{Domněnka otcovství dle $§ 778$ ObčZ}

\section{1 Asistovaná reprodukce}

Domněnka otcovství, na níž je v tomto příspěvku primárně zaměřena pozornost, velice úzce souvisí s pojmem, asistovaná reprodukce‘. Ve snaze o ucelený výklad dané problematiky je proto vhodné alespoň stručně právní rámec asistované reprodukce přiblížit. 


\section{PRÁVNE ROZPRAVY ON-SCREEN III. - Sekcia súkromného práva}

online vedecká konferencia - 7. máj 2021

Asistovaná reprodukce představuje jednu ze specifických zdravotních služeb, jež je regulována $§ 3$ - 11 zákona o specifických zdravotních službách. ${ }^{4}$ Ustanovení $§ 3$ odst. 1 ZSZSI ji definuje jako soubor metod a postupů, jichž je užíváno za účelem provedení umělého oplodnění ženy ve dvou taxativně vymezených případech - bud' jako subsidiární formy léčby neplodnosti ženy či muže z neplodného páru, nebo jako způsobu včasného vyšetření budoucího dítěte $\mathrm{z}$ důvodu rizika přenosu geneticky podmíněných chorob, jejichž původci mohou být žena či muž z neplodného páru. Umělé oplodnění je tedy primárním cílem, za nímž jsou metody a postupy asistované reprodukce prováděny. Př́ístup k němu má pouze subjekt označovaný jako neplodný pár tvořený mužem a ženou, kteří hodlají podstoupit tuto zdravotní službu společně (§ 6 odst. 1 ZSZS1). Vztah mezi mužem a ženou v neplodném páru přitom není nijak podstatný; může být tvořen manžely, ale i osobami nesezdanými, či dokonce osobami, mezi nimiž žádný hlubší citový vztah neexistuje. ${ }^{5}$ Neplodný pár činí v rámci asistované reprodukce různá právní jednání, zejména udílí souhlas k provedení umělého oplodnění ( 8 odst. 2 ZSZS1), na nějž je navázána v tomto příspěvku analyzovaná domněnka.

\section{2 Úprava domněnky vázané na souhlas k provedení umělého oplodněnív ObčZ}

Domněnka vázaná na udělení souhlasu k provedení umělého oplodnění je v rámci české právní úpravy domněnkou nejmladší. Poprvé byla do české právního řádu zakotvena s účinností od 1. 6. 2006, jímž byl do $§ 54$ tehdy platného a účinného zákona o rodině zákonem č. 227/2006 Sb. přidán odst. 3, ${ }^{6}$ který upravoval soukromoprávní důsledky provedení umělého oplodnění v rámci nesezdaného páru. ${ }^{7} \mathrm{Na}$ tuto úpravu navázal i stávající občanský zákoník, jenž tuto domněnku reguluje v § 778 takto: „Narodí-li se dítě, které je počato umělým oplodněním, ženě neprovdané, má se za to, že otcem dítěte je muž, který dal k

\footnotetext{
${ }^{4}$ Zák. č. 373/2011 Sb., o specifických zdravotních službách, ve znění pozdějších předpisů (dále jen „ZSZSl“).

${ }^{5}$ FRINTA, O. Asistovaná reprodukce - nová právní úprava. Právní fórum [online]. 2007, č. 4, s. 123-130 [cit. 30. 5. 2021]. Dostupné https://www.noveaspi.cz/products/lawText/7/35406/1/2?vtextu=asistovan $\% \mathrm{C} 3 \% \mathrm{~A} 1 \% 20$ reprodukce $\% 20$ \%20metoda $\% 20 \mathrm{pr} \% \mathrm{C} 3 \% \mathrm{~A} 1 \mathrm{vn} \% \mathrm{C} 3 \% \mathrm{AD} \% 20 \% \mathrm{C} 3 \%$ BApravy\#lema0.

${ }^{6}$ Srov. § 54 odst. 3 zák. č. 94/1963 Sb., o rodině, ve znění účinném od 1. 1. 2006 do 31. 12. 2013: „Je-li dítě počato umělým oplodněním ženy z asistované reprodukce podle zvláštního právního předpisu, považuje se za otce muž, který dal k umělému oplodněni ženy podle tohoto zvláštního právního předpisu souhlas, pokud by se neprokázalo, že žena otěhotnéla jinak. “

${ }^{7}$ Srov. § 26 zák. č. 227/2006 Sb., o výzkumu na lidských embryonálních kmenových buňkách a souvisejících činnostech a o změně některých souvisejících zákonů, ve znění účinném do 31. 12. 2013.
} 


\section{PRÁVNE ROZPRAVY ON-SCREEN III. - Sekcia súkromného práva}

online vedecká konferencia - 7. máj 2021

umělému oplodnění souhlas. " Ze znění ObčZ je tak patrné, že otcem dítěte je zde muž z neplodného páru vymezeného v $§ 6$ odst. 1 ZSZS1.

Občanský zákoník této domněnce věnuje ještě jedno ustanovení, v němž se zabývá podmínkami a možnostmi pro její popření. Dle $\S 787$ ObčZ narodilo-li se dítě v době mezi 160. a 300. dnem od umělého oplodnění provedeného se souhlasem manžela matky, nebo jiného muže, není-li matka vdaná, nelze otcovství popřít, ledaže se prokáže, že matka dítěte otěhotněla jinak; př́íp. pokud se prokáže, že domněnka vůbec nemá danému muži svědčit. ${ }^{8}$ Vyloučena je současně explicitně možnost popřít otcovství z důvodu neshody právního a biologického otcovství, ${ }^{9}$ což je pravidelný a nejčastější důvod pro popření jak domněnky manžela matky, tak domněnky vázané na učinění souhlasného prohlášení, který je veden myšlenkou, že právní otcovství by mělo pokud možno odpovídat otcovství biologickému (i sociálnímu). V př́ípadě domněnky dle $\S 778$ ObčZ je však nutno brát v úvahu zvláštní povahu umělého oplodnění, jež bytostně souvisí s analyzovanou domněnkou. Pokud je jeho specifikum zohledněno, omezení co do důvodů pro popírání je zcela logické. Umělé oplodnění lze provést bud' za použití zárodečných buněk samotného neplodného páru, nebo za použití gamet anonymního dárce či dárců. Současně je nutné zdůraznit, že dárcovství zárodečných buněk je dle platné právní úpravy zásadně anonymní, a to jak ve vztahu dárce a př́jemce gamet, tak ve vztahu dárce a dítěte z umělého oplodnění narozeného - dítě nemá možnost zjistit identitu anonymního dárce, nanejvýše mu lze po dosažení zletilosti $z$ důležitých důvodů zpř́ístupnit informace o zdravotním stavu anonymního dárce ( $§ 10$ ZSZSI). Je tedy zřejmé, že v některých případech určení otcovství na základě této domněnky již z povahy věci právní a biologické otcovství nemohou být v souladu, a současně, že je ani do vzájemného souladu nelze uvést, když taková možnost by byla v př́mém rozporu s požadavkem na anonymitu dárcovství zárodečných buněk.

Výše uvedená limitace co do důvodů pro popření otcovství určeného na základě domněnky dle $\S 778$ ObčZ se však neuplatní, narodilo-li se dítě před 160. dnem, či po 300. dnu od provedení umělého oplodnění. Z čistě jazykového výkladu za použití argumentu $a$ contrario by bylo možno dovodit, že mimo vymezený časový úsek lze popírat otcovství např̀. i z důvodu nesouladu biologického a právního otcovství. Nicméně v tomto ohledu se lze

\footnotetext{
${ }^{8}$ Shodně ŠÍNOVÁ, R. § 778. In: MELZER, F., TÉGL, P. a kol. Občanský zákoník - velký komentář. Svazek IV. $\S$ 655-975. Praha: Leges, 2016, s. 893.

${ }^{9}$ Srov. $\$ 787$ ObčZ: ,, Otcovství nelze popřit $k$ dítěti narozenému v době mezi stošedesátým dnem a třistým dnem od umélého oplodnéni provedeného se souhlasem manžela matky, nebo se souhlasem jiného muže, když matka není vdaná, bez ohledu na to, jaké genetické látky bylo použito. To neplatí, otěhotněla-li matka dítěte jinak. “.
} 


\section{PRÁVNE ROZPRAVY ON-SCREEN III. - Sekcia súkromného práva}

online vedecká konferencia - 7. máj 2021

domnívat, že takový výklad by byl jen čistým formalismem. Vhodnějším se zdá přistoupit na flexibilní výklad, který by reflektoval okolnosti každého jednotlivého př́padu - rozdíl jistě bude mezi tím, pokud se dítě narodilo 159. a 350. den od provedení umělého oplodnění. V prvé situaci lze usuzovat např. na výjimečně krátkou dobu těhotenství či předčasný porod, zatímco v situaci druhé již bude velice pravděpodobné, že k otěhotnění ženy muselo dojít jiným způsobem než na základě provedení umělého oplodnění. V prvním prrípadě tak jistě nebude vhodné automaticky popírat otcovství jen kvůli nesouladu biologického a právního otcovství. Rozhodnutí, zda bude možno otcovství k dítěti narozenému mimo vymezený časový úsek v $\S 787$ ObčZ popírat v intencích tohoto ustanovení, nebo bez omezení, by mělo v konečném důsledku náležet soudu, který o popření otcovství bude rozhodovat, přičemž by měly být zohledněny okolnosti každého př́padu i zájmy všech dotčených osob, v prvé řadě narozeného dítěte.

\section{Absence popěrných lhůt - význam, důsledky a možná řešení}

\section{1 Úvodní poznámky}

Z výše uvedené právní úpravy domněnky vázané na souhlas k provedení umělého oplodnění je patrné, že oproti úpravě ostatních domněnek není ucelená a některé podstatné náležitosti v ní obsaženy nejsou, zejména co se jejího popírání týče. V prvé řadě jde o absenci vymezení osob disponujících popěrným právem. Tento problém je však v konečném důsledku bez většího významu, nebot' jej lze poměrně jednoduše překlenout interpretačně za pomoci úpravy domněnek ostatních. Popěrným právem obecně disponují v českém právním řádu jen matka a otec dítěte, výjimečným případem je popěrné právo soudu z moci úřední, které se však kvůli zásadě enumerace veřejnoprávních pretenzí1 ${ }^{10}$ uplatní výlučně v případě domněnky vázané na souhlasné prohlášení. ${ }^{11}$ Pro jiné osoby v současné době popěrné právo dovodit nelze, byt' je samozrrejmě otázkou, zda by jím též neměly za určitých okolností disponovat

\footnotetext{
${ }^{10}$ Tato zásada nachází své vyjádření např. v čl. 2 odst. 3 Ústavy České republiky (úst. zák. č. 1/1993 Sb., ve znění pozdějších předpisů): „Státní moc slouži všem občanům a lze ji uplatňovat jen $v$ prrípadech, $v$ mezích a způsoby, které stanoví zákon.".

${ }^{11}$ Srov. § 793 ObčZ věta první: „Vyžaduje-li to zrèejmý zájem ditěte a maji-li být naplněna ustanovení zaručujicí základní lidská práva, mưže soud i bez návrhu zahájit řizení o popření otcovství, bylo-li otcovství určeno souhlasným prohlášením rodičů, ale otec ditěte takto určený nemůže být jeho otcem. “.
} 


\section{PRÁVNE ROZPRAVY ON-SCREEN III. - Sekcia súkromného práva}

online vedecká konferencia - 7. máj 2021

(např. domnělý otec či dítě) - nicméně toto je již otázka překračující rámec tohoto př́íspěvku, když se váže ke koncepci popěrného práva jako takového.

Významnějším problémem však je absence samotných popěrných lhůt, v nichž mohou matka a otec dítěte otcovství popřít, nebot' ze samotného ustanovení $§ 787$ ObčZ se explicitně délka popěrné lhůty nepodává. Samožrejmě si lze klást otázku, proč právě absence popěrné lhůty představuje problém. Účelem popěrné lhůty je vymezit úsek, v němž mohou oprávněné osoby zákonem předvídaným způsobem zasáhnout do existujícího statusového poměru a dosáhnout jeho zrušení. Popěrné právo jako takové pak slouží k ochraně práv (např. právo na rodinný a soukromý život) osob, které jím disponují, aby mohly vést do souladu nekorespondující právní, biologickou a sociální realitu. Do značné míry se ovšem popěrné právo dostává do kolize se zájmem dítěte na co nejvčasnějším určení a stabilizaci statusových poměrů - jinými slovy na tom, aby dítě co nejdř́ve po narození mělo dva právní rodiče, dvě osoby s právy a povinnostmi $\mathrm{k}$ němu). Zájem na stabilitě právních poměrů dítěte přitom sleduje i nyní analyzovaná domněnka - pokud by neexistovala, dítě narozené neprovdané ženě by mnohdy muselo čekat měsíce či roky, než by „Získalo“ právního otce prostřednictvím souhlasného prohlášení jeho matky a nějakého muže. Z důvodu těchto vzájemně si konkurujících zájmů dítěte a osob s popěrným právem musí být možnost domoci se popření otcovství jasně časově ohraničena, k čemuž slouží právě popěrné lhůty.

Obdobný názor na popěrné lhůty plyne i z judikatury, a to jak české, tak Evropského soudu pro lidská práva (ESLP). Český Ústavní soud v nálezu ze dne 8. 7. 2010, sp. zn. Pl. ÚS 15/09 uvedl, že popěrné lhůty samy o sobě nejsou protiústavní, nicméně nemohou být neomezené; resp. jejich protiústavnost nenastává prima facie a je naopak závislá na konkrétních okolnostech. Současně je podstatné, ne-li významnější než samotná délka lhůty, určení jejího počátku, jenž nemůže být vázán na čistě objektivní skutečnost, aniž by současně nereflektoval, kdy právní otec získal důvodné pochybnosti o svém otcovství. ${ }^{12}$ Tímto nálezem Ústavní soud navázal na konstantní judikaturu ESLP, z níž např. v rozhodnutí Shofman v. Rusko plyne, že omezení možnosti popřít otcovství je standardem napříč evropskými státy, který je odůvodněn zájmem na zachování stability v rodinných vztazích, přičemž jen minimum států popěrné právo časově neomezuje. Nicméně pokud však právní úprava běh popěrné lhůty váže výlučně na objektivní skutečnost a nezohledňuje okamžik, kdy právní otec nabyl pochybnosti o svém otcovství, jsou tím porušena práva otce garantována čl. 8

\footnotetext{
${ }^{12}$ Nález Ústavního soudu ze dne 8. 7. 2010, sp. zn. Pl. ÚS 15/09.
} 


\section{PRÁVNE ROZPRAVY ON-SCREEN III. - Sekcia súkromného práva}

online vedecká konferencia - 7. máj 2021

Úmluvy. ${ }^{13,14}$ Jsou-li výše citovaná rozhodnutí konfrontována se stávající českou úpravu popírání domněnky otcovství dle $\S 778$ ObčZ, je patrné, že zákonná úprava požadavkům kladeným judikaturou neodpovídá, což jistě není žádoucí.

\section{2 Di̊sledky absence popěrných lhưt v různých př́ipadech}

\section{2. 1 Situace $A$}

Byt' je tedy možno českou právní úpravu co do absence vymezení popěrné lhůty kritizovat, je nutné zdůraznit, že míra kritiky, resp. důsledků plynoucích z absence popěrné lhůty, se bude lišit v závislosti na tom, jakému neplodnému páru se dítě narodilo. Rozlišit lze $\mathrm{v}$ zásadě tři různé situace, a to jednak dle toho, jaké osoby tvořily neplodný pár, a současně dle toho, do jakého typu soužití se dítě následně po provedení umělého oplodnění narodilo.

V první z nich - v situaci A - se dítě narodilo to manželství (příp. v ochranné lhůtě po jeho zániku - viz $§ 776$ odst. 1 ObčZ) a současně manžel matky netvořil součást neplodného páru, a tedy neudělil souhlas s provedením umělého oplodnění. Tato situace je nejjednodušší a co do otázky popěrných lhůt zde žádné problémy nenastávají. Plně se zde totiž z důvodu přednosti uplatní domněnka manžela matky, a to na základě faktu, že dítě se narodilo do manželství. Ani popírání otcovství v tomto prŕípadě nebude nijak limitováno (ani časově, ani co do důvodů) - beze zbytku bude možno použít popěrné lhůty manžela matky, a to jak pro něj samotného (šest měsíců a šest let), tak pro matku dítěte (šest měsíců). ${ }^{15}$

\section{2. 2 Situace B}

Velmi podobný závěr o problematičnosti absence popěrné lhůty jako v předchozím př́padě lze přijmout i v situaci B. I zde se dítě narodilo za trvání manželství (příp. v ochranné době po jeho zániku), manžel ovšem již tvořil neplodný pár s matkou dítěte, a tedy udělil souhlas k provedení umělého oplodnění. Pro určení otcovství se opět plně uplatní domněnka manžela matky dle $\S 776$ odst. 1 ObčZ. Popření otcovství však v tomto př́ípadě bude modifikováno ustanovením $\S 787$ ObčZ, a to co do důvodů pro popření. Tato limitace je

\footnotetext{
${ }^{13}$ Rozhodnutí Evropského soudu pro lidská práva ze dne 24. 11. 2005, Shofman v. Rusko, č. 74826/01.

14 Čl. 8 odst. 1 Úmluvy o ochraně lidských práv a základních svobod, vyhlášené sdělením federálního ministerstva zahraničních věcí č. 209/1992 Sb.: „Každý má právo na respektování svého soukromého a rodinného života, obydli a korespondence. ".

${ }^{15}$ Shodně ŠÍNOVÁ, R. § 787. In: MELZER, F., TÉGL, P. a kol. Občanský zákoník - velký komentář. Svazek IV. $\S 655-975$. s. $962-963$.
} 


\section{PRÁVNE ROZPRAVY ON-SCREEN III. - Sekcia súkromného práva}

online vedecká konferencia - 7. máj 2021

poměrně logická, když sleduje zájem na zachování stability statusových poměrů narozeného dítěte, a zároveň respektuje svébytnou povahu heterologního ${ }^{16}$ umělého oplodnění (viz podkapitola 2. 2). Co se týče délky i počátku běhu popěrných lhưt, ani v situaci B nenastává větší problém, když se v důsledku aplikace domněnky manžela matky uplatní i popěrné lhůty svázané s touto domněnkou (tedy opět kombinace šestiměsíční a šestileté popěrné lhůty pro manžela a šestiměsíční lhůty pro matku). ${ }^{17}$

\section{2. 3 Situace $C$}

Konečně nejzajímavější a současně nejproblematičtější situaci, v níž se plně projevují nedostatky stávající právní úpravy, představuje situace C. Zde se dítě narodilo nesezdanému páru, který současně tvořil i neplodný pár. V tomto př́padě nachází při určení otcovství plné uplatnění domněnka dle $\S 778$ ObčZ. Pro popření otcovství se pak aplikuje výlučně $§ 787$ ObčZ. Na tomto místě ovšem nastává kámen úrazu v podobě absence popěrných lhůt. Za současného stavu právní úpravy, která pro tento př́ípad popěrné lhůty neobsahuje, se tak nabízí závěr, že možnost popírat otcovství určené v situaci $\mathrm{C}$, je časově neomezená ( $\mathrm{z}$ hlediska důvodů pro popření zde nachází plné uplatnění limitace z $§ 787$ ObčZ). ${ }^{18}$ Jak již však bylo uvedeno, takový závěr není souladný s judikaturou českou ani ESLP.

\section{3 Řěsení absence popěrných lhůt ve skupině C}

\section{3. 1 Novelizace Obč Z}

Již na první pohled je patrné, že stávající koncepce české právní úpravy týkající se popření domněnky otcovství dle $\S 778$ ObčZ pro nesezdané páry není ideální, když (vedle nesouladu s judikaturou) působí značnou právní nejistotu zejména pro narozené dítě, jemuž může být za současného právního stavu do statusových poměrů zasaženo prakticky bez časového omezení. Je tedy více než vhodné tuto mezeru v zákoně určitým způsobem vyplnit. Jako první a patrně nejjednodušší řešení se nabízí novelizace ObčZ a doplnění $§ 787$ o

\footnotetext{
${ }^{16}$ Tímto termínem je označováno umělé oplodnění, při němž bylo užito zárodečných buněk anonymního dárce či dárců. Naproti tomu umělé oplodnění, při němž je užito výlučně zárodečných buněk neplodného páru je označováno jako ,homologní'.

${ }^{17}$ Shodně ŠÍNOVÁ, R. § 787. In: MELZER, F., TÉGL, P. a kol. Občanský zákoník-velký komentář. Svazek IV. § 655-975. s. 963.

${ }^{18}$ Ibidem.
} 


\section{PRÁVNE ROZPRAVY ON-SCREEN III. - Sekcia súkromného práva}

online vedecká konferencia - 7. máj 2021

popěrné lhůty (např. ve formě přidání dalšího odstavce, jenž by bud' upravil lhůty speciální, nebo by odkázal výslovně na užití lhůt jiných).

V kontextu tohoto řešení se však hodí poznamenat, že při zakotvení nových, speciálních lhůt do $§ 787$ ObčZ by muselo být pečlivě zvažováno, jaký důsledek by tato změna měla pro situaci $\mathrm{B}$, která již do určité míry ustanovením $§ 787$ ObčZ co do důvodů pro popření modifikována je. Již bylo uvedeno, že v situaci B se díky přednosti domněnky dle $\S$ 776 odst. 1 ObčZ uplatní i popěrné lhůty manžela matky. Pokud by však ustanovení $§ 787$ ObčZ obsahovalo lhůty odlišné od těch již existujících v $§ 785$ odst. 1 ObčZ, vznikl by konflikt, jaké lhůty by se v situaci $B$ měly uplatnit. Tedy zda by skutečnost, že došlo k provedení umělého oplodnění se souhlasem manžela matky, měla mimo limitovaných, avšak odůvodněných (viz již dřive) důvodů pro popření, ovlivnit i délku popěrných lhůt. Lze se domnívat, že takové další omezení by nebylo správné, resp. postrádalo by rozumný důvod, a založilo by jen nerovnost mezi různými manželskými páry. Proto lze doporučit, aby pro případ zakotvení popěrných lhůt do $§ 787$ ObčZ bylo spíše zvoleno řešení odkazem na užití lhůt již existujících (př́íp. aby byla provedena revize popěrných lhůt jako takových v rámci všech domněnek otcovství, což je však problematika jdoucí nad rámec primárního zaměření tohoto příspěvku).

\section{3. 2 Úvaha nad př́pustností analogie}

Mimo výše uvažované možnosti novelizace př́slušných ustanovení občanského zákoníku, si lze položit otázku, zda by nebylo možno tuto objektivně existující mezeru ve stávající právní úpravě překlenout interpretačně, resp. za pomoci analogické aplikace popěrných lhůt z jiných domněnek otcovství. Tento závěr upřednostňuje část komentářové literatury, jež bez dalšího odkazuje na použití popěrných lhůt manžela matky, tj. kombinace objektivní šestileté a subjektivní šestiměsíční lhůty. ${ }^{19} \mathrm{~S}$ tímto závěrem se však nelze plně ztotožnit, a to z několika důvodů.

Předně je třeba uvést, že ačkoli lze jistě pochopit snahu o analogické uplatnění lhůt jiných, která by do značné míry redukovala nejistotu právních poměrů dítěte, jež dnes v rámci analyzované domněnky bezpochyby existuje, je otázkou, zda by analogická aplikace lhůt jiných nezasáhla naopak do práv ostatních osob, zejména těch disponujících popěrným

\footnotetext{
${ }^{19}$ KRÁLÍČKOVÁ, Z. § 778 [Domněnka v případě umělého oplodnění neprovdané matky]. In: KRÁLíČKOVÁ, Z., HRUŠÁKOVÁ, M., WESTPHALOVÁ, L. a kol. Občanský zákoník II. Rodinné právo (\$ 655-975). Komentár. 2. vyd. Praha: C. H. Beck, 2020, s. 512.
} 


\section{PRÁVNE ROZPRAVY ON-SCREEN III. - Sekcia súkromného práva}

online vedecká konferencia - 7. máj 2021

právem. V současné době tyto osoby co do lhůty nijak zákonem výslovně limitovány nejsou; mělo-li by však dojít k omezení jejich popěrného práva na základě analogie (tedy aniž by tak bylo výslovně určeno zákonem), nebyl by to patrně postup souladný s čl. 2 odst. 3 Listiny základních práv a svobod, ${ }^{20}$ který říká, že každý může činit, co není zákonem zakázáno, a nikdo nesmí být nucen činit, co zákon neukládá. ${ }^{21}$ Přitom i jedno z úvodních, výkladových ustanovení ObčZ ( 2 odst. 1) říká, že každé ustanovené soukromého práva lze vykládat jen ve shodě s Listinou základních práv a svobod, ústavním pořádkem vůbec, zásadami, na nichž spočívá ObčZ, jakož i trvalým zřetelem k hodnotám, které se tím chrání. Osoby disponující popěrným právem (zejména otec dítěte) přitom mohou za současného právního stavu legitimně očekávat a spoléhat se na znění právní úpravy - nevýslovné a analogické omezení osobnostních práv tak může představovat zásah do jejich vlastní právní jistoty. Byt' je snaha o existenci jistoty a stability v právních poměrech dítěte legitimním cílem, mělo by této stability být dosahováno pro adresáty právních norem jasným a předvídatelným způsobem, aby měli možnost se s omezením popěrných lhůt předem seznámit - tedy jinými slovy, tyto lhůty by měly být výslovně v ObčZ upraveny.

I kdyby však byla připuštěna možnost analogického užití lhůt jiných, nebylo by možno prve uvedenému závěru přisvědčit zcela. Problém by analogie jistě nečinila (a to nakonec ani v kontextu úvahy o souladu s úpravou Listiny základních práv a svobod), pokud jde o popěrnou lhůtu pro matku dítěte. Zde by se vždy nabízela pouze šestiměsíční objektivní lhůta, když jiné popěrné lhůty pro matku dítěte český právní řád neobsahuje. V případě otce dítěte je však situace o něco komplikovanější. Výše citovaný závěr odkazuje na analogické užití lhůt manžela matky, aniž by bylo zřejmé, na jakém základě tak činí (zejména jde-li se o nesezdaný pár). Jedním z možných argumentů by mohlo být, že nesezdaný pár se nachází v obdobném postavení jako manželé. ${ }^{22}$ Nicméně s tímto argumentem nelze plně souhlasit. Z výše uvedeného textu se podává, že domněnka dle $§ 778$ ObčZ se ve své „ryzi““ podobě uplatňuje pouze v situaci $\mathrm{C}$, tj. tehdy, když byl neplodným párem pár nesezdaný, a současně narodilo-li se dítě do tohoto (či jiného) nesezdaného soužití. V situacích A a B (jejichž podobnost by mohla být namítána) byla klíčovou okolností pro určení otcovství k narozenému dítěti

\footnotetext{
${ }^{20}$ Usnesení předsednictva ČNR č. 2/1993 Sb., o vyhlášení Listiny základních práv a svobod jako součásti ústavního pořádku České republiky, ve znění pozdějších předpisů.

${ }^{21}$ Tento závěr zastává např. ŠíNOVÁ, R. § 787. In: MELZER, F., TÉGL, P. a kol. Občanský zákoník - velký komentár. Svazek IV. § 655-975. s. 963 - 964.

$22 \S 10$ odst. 1 ObčZ k analogii legis uvádí: „Nelze-li právní př́pad rozhodnout na základè výslovného ustanovení, posoudí se podle ustanovení, které se týká právniho prípadu co do obsahu a účelu posuzovanému právnímu prípadu nejbližšiho. “.
} 


\section{PRÁVNE ROZPRAVY ON-SCREEN III. - Sekcia súkromného práva}

online vedecká konferencia - 7. máj 2021

existence manželství, nikoli udělení souhlasu k provedení umělého oplodnění (s výjimkou situace $\mathrm{B}$, kdy hrála roli co do důvodů pro popření) - plně zde převládla domněnka manžela matky. Byt' se tedy právní rodiče dítěte $\mathrm{v}$ situaci $\mathrm{C}$ mohou na první pohled nacházet v postavení obdobném jako právní rodiče $\mathrm{v}$ situacích $\mathrm{A}$ i $\mathrm{B}$, jedná se jen o podobnost zdánlivou, kdy je otcovství určováno na základě odlišných důvodů, a nakonec i odlišných mechanismů (viz dále). Společné v jejich postavení je pouze to, že došlo k provedení umělého oplodnění - význam tohoto faktu je však u každé situace odlišný (viz podkapitola 3. 2). Výjimku představuje určitá shoda v situacích B a C, kdy se však shodují toliko di̊vody pro popření otcovství.

Současně, je-li uvážena podobnost jednotlivých domněnek otcovství, je domněnka vázaná na udělení souhlasu k provedení umělého oplodnění podobnější více domněnce vycházející ze souhlasného prohlášení, když obě jsou založeny právním jednáním určitých osob či osoby, a obě se aplikují na nesezdaný pár. ${ }^{23}$ Domněnka manžela matky se naproti tomu uplatňuje zcela automaticky, pouze na základě faktu existence manželství. Stejně, jako je navrhováno analogické užití lhůt manžela matky, by tak mohlo být navrhováno obdobné užití lhůt muže, jenž učinil souhlasné prohlášení. I tato analogická aplikace lhưt by však byla ve svém důsledku poměrně problematická. De facto by totiž byla aplikována poměrně krátká lhůta (6 měsíců) s objektivně určeným počátkem, jež by nijak nereflektovala, kdy se muž dozvěděl o tom, že žena otěhotněla jinak (tato okolnost ostatně byla důvodem, který vedl Ústavní soud ke zrušení předchozí úpravy popěrné lhůty manžela matky v nálezu sp. zn. Pl. ÚS 15/09 z 8. 7. 2010, a která je setrvale předmětem kritiky popěrné lhůty muže, jenž učinil souhlasné prohlášení, kde tento problém přetrvává i po přijetí ObčZ). ${ }^{24}$

K uvedenému lze jen na okraj poznamenat, že tento problém - zda a příp. jaké popěrné lhůty analogicky aplikovat - by nemusel nastat, pokud by česká právní úprava vypadala jinak a byla více podobná například úpravě slovenské. V té jsou popěrné lhůty nastaveny jednotně, a to jak pro matku i otce dítěte, tak pro domněnku manžela matky a domněnku založenou súhlasným vyhlasenim rodičov. Ve všech př́ípadech je popěrná lhůta tř́letá. ${ }^{25}$ Byla-li by i

\footnotetext{
${ }^{23}$ Srov. $\$ 779$ odst. 1 věta prvá ObčZ: „Nedojde-li k určení otcovství podle § 776, 777 nebo 778, má se za to, že otcem je muž, jehož otcovství bylo určeno souhlasným prohlášením matky a tohoto muže. “.

${ }^{24}$ SCHÖN, M. Lhůty pro popírání otcovství. In: KOTÁSEK, J. (ed.). Dny práva 2012 - Days of Law 2012 [online]. Brno: Masarykova univerzita, 2013, s. 1324 - 1326 [cit. 30. 5. 2021]. Dostupné z: https://www.law.muni.cz/sborniky/dny prava 2012/files/sbornik.pdf.

${ }^{25}$ Srov. $\S 86$ odst. $1, \S 88$ odst. 2 a $\S 93$ odst. 1 a 2 zák. č. 36/2005 Z. z., o rodine a o zmene a doplnení niektorých zákonov, ve znení neskorších predpisov. Současně je však nutno konstatovat, že i v rámci slovenské úpravy se popěrné lhůty, byt' co do délky sjednoceny, liší v rámci jednotlivých domněnek co do svého počátku,
} 


\section{PRÁVNE ROZPRAVY ON-SCREEN III. - Sekcia súkromného práva}

online vedecká konferencia - 7. máj 2021

česká právní úprava co do délky popěrných lhůt (alespoň pro otce) jednotná, příp. jednotná i co do stanovení svého počátku, pak by jistě o analogickém užití lhưt jiných v rámci domněnky vázané na udělení souhlasu k provedení umělého oplodnění bylo možno uvažovat. Přitom by zde patrně nemusel ani nastat problém střetu takového výkladu s Listinou základních práv a svobod, když by osoby disponující popěrným právem mohly z konzistentnosti právní úpravy očekávat, že jsou-li veškeré popěrné lhůty pro ostatní domněnky otcovství totožné, bude (byla by) stejná i lhůta pro popření této domněnky.

\section{Záver}

Jakkoli se může na první pohled zdát, že problematika popírání otcovství v případě, kdy se dítě narodilo díky umělému oplodnění, je ryze teoretickou záležitostí, vzrůstající oblíbenost a četnost provádění metod asistované reprodukce ji činí vysoce aktuální a prakticky využitelnou. Lze shrnout, že česká právní úprava popírání domněnky otcovství vázané na souhlas k provedení umělého oplodnění neprovdané ženy není ideální a obsahuje několik podstatných bílých míst. Vedle otázky osob disponujících popěrným právem, jež však i přes absenci výslovné úpravy nečiní větších potíží (snad s výjimkou úvahy, zda je takto úzký okruh oprávněných subjektů vyhovující), je to především otázka absence jasného vymezení popěrných lhůt. Byt' v rámci odborné literatury jsou přítomny názorové proudy, které navrhují překlenout tuto mezeru v zákoně výkladem a obdobně užít jiné, již existující lhůty (jmenovitě lhůty $\mathrm{z}$ domněnky manžela matky), jeví se toto řešení přinejmenším v př́ípadě otce dítěte problematickým. Stávající česká právní úprava neposkytuje dotčeným osobám jakékoli vodítko, z něhož by mohly na analogickou aplikaci konkrétních popěrných lhůt usuzovat naopak je utvrzuje v přesvědčení, že jejich možnost popřít otcovství je v zásadě omezena pouze důvody, nikoli však časově.

Ačkoli je evidentní, že existence popěrného práva, jež není nijak časově limitováno, není souladná se závěry judikatury české, ani Evropského soudu pro lidská práva, a působí značnou právní nejistotu zejména pro narozené dítě, zdá se vhodnějším pro všechny zainteresované subjekty popěrné lhůty v zákoně upravit výslovně. Přitom by v zásadě bylo lhostejno, zda by tak zákonodárce učinil výslovnou úpravou lhůty nové, či „,jen“ výslovným

kdy tento je u domněnky manžela matky nastaven ryze subjektivně, zatímco u domněnky založené souhlasným prohlášením je objektivní. 


\section{PRÁVNE ROZPRAVY ON-SCREEN III. - Sekcia súkromného práva}

online vedecká konferencia - 7. máj 2021

odkazem na užití lhůt již existujících. V kontextu této de lege ferenda navrhované změny pak lze jen doplnit, že současně by měl zákonodárce uvažovat i nad revizí popěrných lhůt a určení jejich počátků jako takovými, a př́íp. je sjednotit, či minimálně uvést do souladu se závěry judikatury.

\section{ZOZNAM BIBLIOGRAFICKÝCH ODKAZOV}

\section{Komentáre:}

KRÁLÍČKOVÁ, Z., HRUŠÁKOVÁ, M., WESTPHALOVÁ, L. a kol. Občanský zákoník II. Rodinné právo (§ 655-975). Komentáŕ. 2. vyd. Praha: C. H. Beck, 2020, 1250 s. ISBN $978-$ 80-7400-795-8.

MELZER, F. - TÉGL, P. a kol.: Občanský zákoník - velký komentář. Svazek IV. § 655-975. 2064 s. ISBN 978-80-7502-004-8.

\section{Periodiká a zborníky:}

FRINTA, O. Asistovaná reprodukce - nová právní úprava. Právní fórum [online]. 2007, č. 4, S. 123-130 [cit. 30. 5. 2021]. Dostupné Z: https://www.noveaspi.cz/products/lawText/7/35406/1/2?vtextu=asistovan\%C3\%A1\%20repro dukce $\% 20-\% 20$ metoda $\% 20 \mathrm{pr} \% \mathrm{C} 3 \% \mathrm{~A} 1 \mathrm{vn} \% \mathrm{C} 3 \% \mathrm{AD} \% 20 \% \mathrm{C} 3 \% \mathrm{BApravy} \#$ lema0.

SCHÖN, M.: Lhůty pro popírání otcovství. In: KOTÁSEK, J. (ed.).: Dny práva 2012 - Days of Law 2012 [online]. Brno: Masarykova univerzita, 2013, s. 1316 - 1326 [cit. 30. 5. 2021]. ISBN 978-80-210-6319-8. 9ostupné Z: https://www.law.muni.cz/sborniky/dny prava 2012/files/sbornik.pdf.

\section{Právne predpisy:}

Zák. č. 94/1963 Sb., o rodině, ve znění účinném od 1. 1. 2006 do 31. 12. 2013.

Úmluva o ochraně lidských práv a základních svobod, vyhlášená sdělením federálního ministerstva zahraničních věcí č. 209/1992 Sb.

Úst. zák. č. 1/1993 Sb., Ústava České Republiky, ve znění pozdějších předpisů.

Usnesení předsednictva ČNR č. 2/1993 Sb., o vyhlášení Listiny základních práv a svobod jako součásti ústavního pořádku České republiky, ve znění pozdějších předpisů. 


\section{PRÁVNE ROZPRAVY ON-SCREEN III. - Sekcia súkromného práva}

online vedecká konferencia - 7. máj 2021

Zák. č. 36/2005 Z. z., o rodine a o zmene a doplnení niektorých zákonov, ve znení neskorších predpisov.

Zák. č. 227/2006 Sb., o výzkumu na lidských embryonálních kmenových buňkách a souvisejících činnostech a o změně některých souvisejících zákonů, ve znění účinném do 31 . 12. 2013.

Zák. č. 373/2011 Sb., o specifických zdravotních službách, ve znění pozdějších předpisů.

Zák. č. 89/2012 Sb., občanský zákoník, ve znění pozdějších předpisů.

\section{Judikatúra:}

Rozhodnutí Evropského soudu pro lidská práva ze dne 24. 11. 2005, Shofman v. Rusko, č. $74826 / 01$.

Rozsudek Nejvyššího soudu ze dne 18. 3. 2010, sp. zn. 23 Cdo 5508/2007.

Nález Ústavního soudu ze dne 8. 7. 2010, sp. zn. P1. ÚS 15/09.

(c) (7)

Obsah článku podlieha licencii Creative Commons Attribution 4.0 International Licence CC BY (Denisa Kotroušová). 